\title{
OPEN Author Correction: Plantaricin NC8 $\alpha \beta$ exerts potent antimicrobial activity against Staphylococcus spp. and enhances the effects of antibiotics
}

\section{Torbjörn Bengtsson, Robert Selegård ${ }^{\circledR}$, Amani Musa, Kjell Hultenby, Johanna Utterström, Petter Sivlér, Mårten Skog, Fariba Nayeri, Bengt Hellmark, Bo Söderquist, Daniel Aili@ \& Hazem Khalaf}

Correction to: Scientific Reports https://doi.org/10.1038/s41598-020-60570-w, published online 27 February 2020

The original version of this Article contained an error in the Abstract.

"Of the truncated peptides, $\beta 1-22, \beta 7-34$ and $\beta 1-20$ retained an inhibitory activity."

now reads:

"Of the truncated peptides, $\alpha 1-22, \beta 7-34$ and $\beta 1-20$ retained an inhibitory activity."

In addition, the Authors neglected to cite a key reference related to Lactobacillus plantarum NC8 within the Introduction,

"Strains of Lactobacillus plantarum are generally recognized as probiotic and are used as dietary supplements, and have been reported to express several bacteriocins that belong to class IIb, including PLNC8 $\alpha \beta^{8}$."

now reads:

"Strains of Lactobacillus plantarum are generally recognized as probiotic and are used as dietary supplements, and have been reported to express several bacteriocins that belong to class IIb, including PLNC8 $\alpha \beta^{8}$. These peptides have previously been sequenced and reported to be expressed in the presence of other bacteria, such as Lactococcus lactis MG $1363^{9}$. Full antimicrobial activity of PLNC8 is achieved through the complementary action of both PLNC8 $\alpha$ and $\beta$ in a molar ratio of $1: 16^{9}$." 
(1) Open Access This article is licensed under a Creative Commons Attribution 4.0 International cc) License, which permits use, sharing, adaptation, distribution and reproduction in any medium or format, as long as you give appropriate credit to the original author(s) and the source, provide a link to the Creative Commons licence, and indicate if changes were made. The images or other third party material in this article are included in the article's Creative Commons licence, unless indicated otherwise in a credit line to the material. If material is not included in the article's Creative Commons licence and your intended use is not permitted by statutory regulation or exceeds the permitted use, you will need to obtain permission directly from the copyright holder. To view a copy of this licence, visit http://creativecommons.org/licenses/by/4.0/.

(C) The Author(s) 2020 